IRSH 5 I (2006), pp. 75-92 DOI: I0.I0I7/S0020859005002336

(C) 2006 Internationaal Instituut voor Sociale Geschiedenis

\title{
From "Landsknecht" to "Soldier": The Low German Foot Soldiers of the Low Countries in the Second Half of the Sixteenth Century
}

\author{
ERIK SWART
}

Summary: In the decades after i 550 the soldiery of the Netherlands witnessed the disappearance of the Landsknecht, who had the right to participate in decisionmaking and shape his daily life. He gradually became a mere "soldier", subject to stricter discipline and control. This development accelerated after I 572 because William of Orange needed to maintain the support of the inhabitants of the Netherlands for the Revolt. Better discipline and control over his soldiers were imperative in this. Meanwhile, a progressive process of proletarianization left them largely unable to resist: they simply had nowhere else to go.

The sixteenth century was a period of great social change in Europe. One agent of this change was population growth, which led to migration, urbanization, growing pressure on land use, a rise in prices, and a crisis in the exploitation of labour and the level of wages. ${ }^{\text {I }}$ Those suffering from the resulting impoverishment and misery could find employment in war, which was endemic in large parts of sixteenth-century Europe. There were in fact less than ten years of complete peace. ${ }^{2}$ The near-incessant warfare required large numbers of soldiers, particularly to serve in the increasingly important and numerous infantry. But enlisting seldom provided an escape, since the process of impoverishment in society at large, which also entailed a loss of status and economic power, seems to have been echoed in the armies. Fritz Redlich, for instance, remarked in I964 that the articles of war changed substantially in character during the course of the sixteenth century. From being a contract in which the mutual obligations of government and captains on the one side and soldiers on the other were laid down, they gradually changed into a set of disciplinary precepts, containing no mention of obligations towards the soldiers. ${ }^{3}$ Furthermore,

I. Henry Kamen, European Society 1500-1700 (London [etc.], I984), pp. 3 I-33.

2. Geoffrey Parker, The Military Revolution: Military Innovation and the Rise of the West, I 500-I 800 (Cambridge [etc.], I988; 2nd revised edn, 2000), p. I.

3. Fritz Redlich, The German Military Enterpriser and his Work Force: A Study in European Economic and Social History, 2 vols (Wiesbaden, 1964-1965), vol. I, p. I2I. See also Peter 
the title Landsknecht, worn with pride by German soldiers themselves as late as 1583 as an apparent expression of self-esteem, had all but disappeared by 1600 . They were henceforth simply referred to as soldat. ${ }^{4}$

Until I 560 , economic development in the northern Netherlands conformed to the European trend, with real income and standard of living declining. Thereafter, they began to differ markedly from the trend in neighbouring countries. While prices continued to rise, over the next few decades wages rose even faster.' Nevertheless, the development in the armies alluded to above can also be traced in the Low Countries in the second half of the sixteenth century, particularly after the beginning of the Revolt in Holland and Zeeland in 1572, and most clearly among the Low German foot soldiers. Low Germans (BasAllemands), a classification derived from the language they spoke, was the generic term for soldiers from roughly the area of the later Dutch Republic plus Luxembourg and Limburg. ${ }^{6}$ Both they and the Flemish and Brabantine infantry shared the same organization and institutions with the Landsknechts, which is not surprising since the Netherlands was officially part of the German Empire; but this sharing of organization and institutions has largely gone unnoticed. German historians have even suggested that the Landsknechts had their origin in the Low Countries. ${ }^{7}$

The purpose of this article is to exemplify the changes that took place after c.I550, and especially after I 572, to explain the consequences for the Low German soldiers, and, of course, to account for the driving force behind those changes. The question of why the soldiers themselves did not resist their loss of status and power also needs to be addressed. But we shall first give some information on the social background of ordinary soldiers of the sixteenth century, in particular of those who served in the first two decades of the Dutch Revolt.

Burschel, Söldner im Nordwestdeutschland des 16. und 17. Jabrbunderts. Sozialgeschichtliche Studien (Göttingen, 1994), p. I33.

4. Redlich, The German Military Enterpriser, p. 454; Burschel, Söldner im Nordwestdeutschland, pp. 38-39. For a letter of 1583 from a soldier referring to himself as Landsknecht see Wolfgang Kunze, Leben und Bauten Herzogs Erichs II. von Braunschweig-Lüneburg: Katalog zur historischen Ausstellung im Schloss Landestrost, Neustadt am Rübenberge (Hanover, 1993), p. 179 .

5. Jan de Vries and Ad van der Woude, The First Modern Economy: Success, Failure, and Perseverance of the Dutch Economy, Is00-I8Is (Cambridge, I997), pp. 627-632.

6. Alexandre Henne, Histoire du règne de Charles-Quint en Belgique, Io vols (Brussels [etc.], I $858-$ i 860 ), vol. 3 , pp. $45-47$.

7. Redlich, The German Military Enterpriser, p. 16; Reinhard Baumann, Landsknechte. Ihre Geschichte und Kultur vom späten Mittelalter bis zum Dreißigjährigen Krieg (Munich, 1994), p. i 16; Hans-Michael Möller, Das Regiment der Landsknechte. Untersuchungen zu Verfassung, Recht und Selbstverständnis in deutschen Söldnerbeeren des I6. Jabrhunderts (Wiesbaden, 1976), pp. I, I 50, 202, 227 (n. 223), 259; Henne, Histoire du règne de Charles-Quint, pp. 46-47, 49. 


\section{SOCIAL B A CK GROUND}

The rank and file of an army came from society's economically marginalized individuals. They were generally young men from poor districts with poor prospects. Also, urbanization produced large numbers of urban poor, who were not part of the regular workforce and who proved willing to join the ranks. Some soldiers were fugitives from the law or had been pressed into service; occasionally entire prisons were emptied. Others were adventurers. ${ }^{8}$ The Netherlands was no exception to this. Population growth and inflation had caused the numbers of the impoverished to increase and, with it, the number of potential soldiers. There was a large reservoir of men with few or no social opportunities. In the cities social conflicts arose, the gap between rich and poor became ever wider and unemployment became a mass problem. And although wages began to increase faster than prices from c.I 560 , this was accompanied by a process of proletarianization, which accelerated in the 1580 s, making an increasing number of people entirely dependent on wage labour. ${ }^{9}$

In I 57I bad harvests all over northwestern Europe turned an already poor economic situation into deep crisis. For the Low Countries this came on top of the catastrophic All Saints' Flood of November I 570, which deprived many of house and work. ${ }^{10}$ This meant that there were plenty of potential recruits for the Dutch rebels in Holland and Zeeland in I 572. According to the contemporary historian Pieter Bor, they flocked to the rebel cause in large numbers. Count William van den Bergh, invading Gelre in June I 572 with a commission issued by his brother-in-law William of Orange, had the same experience. Orange's brother, Count Louis of Nassau, had received an influx of men after his victory at Heiligerlee in I568, probably because successful generals offered the prospect of easy money in the form of loot. ${ }^{\mathrm{II}}$ The Sea Beggars formed the nucleus of the rebel force, which emerged in Holland and Zeeland. To a

8. Jan Lindegren, "Men, Money and Means", in Philippe Contamine (ed.), War and Competition Between States (Oxford [etc.], 2000), pp. I29-162, I50-I53; J.R. Hale, War and Society in Renaissance Europe, I450-I620 (London, I985), pp. I I I-I I2, II6-II9, I38; F. Tallet, War and Society in Early Modern Europe, I495-I7IS (London [etc.], I992), pp. 82, 87-88, 90-104. Cf. Bert S. Hall, Weapons and Warfare in Renaissance Europe: Gunpowder, Technology and Tactics (Baltimore, MD [etc.], I997), pp. 230-235.

9. J.L. van Zanden, The Rise and Decline of Holland's Economy: Merchant Capitalism and the Labour Market (Manchester, 1993), pp. 36-38; Geoffrey Parker, The Dutch Revolt (London [etc.], I985; revised edn 2000), pp. 25-26, I26- I 30 ; Burschel, Söldner im Nordwestdeutschland, p. I 56 .

ı. J.C.A. de Meij, De Watergenzen en de Nederlanden I568-1572 (Amsterdam [etc.], 1972), pp. 299-306; M.K. Elisabeth Gottschalk, Stormvloeden en rivieroverstromingen in Nederland, II De periode 1400-I600 (Assen, 1975), pp. 624-707.

I I. Pieter (Christiaensz.) Bor, Oorsprongk, begin, en vervolgh der Nederlandsche oorlogen (Amsterdam, 4th edn, 1679-1684), book 4, pp. 235-236; book 6, p. 367; J. Brouwer, Kronieken van Spaansche soldaten wit het begin van den Tachtigjarigen Oorlog (Zutphen, I933), p. 2 I4. 
large extent they were political and religious refugees from the regime of the Duke of Alba, partly also men pressed into service. But here, too, economic reasons probably dominated, since the largest contingent had enrolled voluntarily. The Sea Beggar captains were nearly all exiles, many from noble families. ${ }^{12}$

Data on the companies of foot serving in North Holland in the first few years after I 572 show the largest contingent (nearly 30 per cent) to be locals, whose main incentive for joining up would have been economic hardship, aggravated still further by the war. Many Germans also served in these units, most probably hailing from northern territories. The striking number of Frisian soldiers in North Holland, and the considerable number of men from Gelre and Overijssel, were almost certainly refugees from the Royal Army, which had regained control over these provinces. Companies in Zeeland show the same makeup, with natives of the province serving alongside refugees (who would have lost everything they had), many of them Walloons and Flemish Wood Beggars or former Wood Beggars. ${ }^{13}$

For the late I 570 and the I 580 s data are far scarcer. A single muster roll from late I 584 appears to continue the pattern in Holland and Zeeland. The largest group of the I07 soldiers in Captain Cornelis van Achthoven's company, mustered at Leiden in South Holland, were from South Holland itself. But no fewer than twenty-four were from the southern provinces of the Netherlands, mainly Brabant and Flanders. They had presumably fled from the advancing troops of the Prince of Parma. ${ }^{14}$ Between 28 June and 27 October I 576 Captain Laurens van Arnhem's company had taken on three men who may have been driven to enlist by temporary unemployment. They were discharged soon after joining up so that they could ply their unspecified trade. One of the Captain's soldiers deserted after raping a woman. The Captain also had a soldier who went on leave to visit his mother on Io October I 576 and, after a period of illness, returned to the company on 10 November. ${ }^{15}$ These cases indicate that in most cases unemployment (temporary or otherwise) and hardship were still probably the main reasons for becoming a soldier. ${ }^{16}$ They also suggest that the generally bad reputation of soldiers among the civilian population was

I 2. De Meij, De Watergeuzen en de Nederlanden, pp. I54-156, I6I-I64.

I3. J.W. Wijn, "Het Noord-Hollandse regiment in de eerste jaren van de opstand tegen Spanje", Tijdschrift voor geschiedenis, 62 (1949), pp. 235-26I, 245-246; muster roll of Johan Schetter's company, 22 May 1573, Nationaal Archief, The Hague (NA), Archives of Paulus Buys I572I 587 , inv. no. 32; M.F. Backhouse, "Guerilla War and Banditry in the I6th Century: The Wood Beggars in the Westkwartier of Flanders (1567-1568)”, Archiv für Reformationsgeschichte, 74 (1983), pp. 232-256, 242-245, $25 \mathrm{I}-254$.

I4. Muster roll dated I6 September I 584, NA, Archives of the Raad van State I $584-1586$, inv. no. 9 .

I5. "Namen dewelche in die platze von die Dode, pasporthen genhommen hebbende, und verlaüffene soldathen wedderumb angenhommen", NA, Paulus Buys, no. 74.

16. Cf. De Vries and Van der Woude, The First Modern Economy, pp. 635-636. 
often well deserved. Others were probably fairly decent characters, although in an environment reputedly permeated with drink, gambling and violence they may not have stayed that way for long.

\section{ABOLITION OF THE LANDSKNECHT ORGANIZATION}

The Landsknechts regarded themselves as an "order", and had their own forms of administration and jurisdiction, as well as customs and habits, which provided strong internal cohesion. The ordinary Landsknechts, the so-called Gemein, were a force to be reckoned with. They regarded themselves as employees and formed a well-organized community with the attributes of a union. Looking after their own interests and participation was fundamental for Landsknechts. The main agents for this were certain company offices, elected monthly by the Landsknechts themselves. These were the two Weifels, the Voerder and the Foerier, ${ }^{17}$ who, besides their daily military duties in the company, were entitled to bring Landsknechts' grievances to their captain. The Voerder could also advise the Landsknechts on their legal rights and serve on their own courts of law. If the regular elected officials failed to achieve anything, special emissaries called Amissaten or Ambossaten could be elected to parley with the colonel or the government. The general purpose of the elected offices was to protect the Landsknechts against highhandedness by the government, non-fulfilment of their contracts, and wrong or new interpretations of the articles of war. Their ultimate weapon in the event of disputes, usually over back pay, was of course the "strike" or mutiny, as the governments who had hired them preferred to call it. ${ }^{18}$ The daily life of the Landsknechts took place in the Rotte of around ten men. They formed these themselves and each Rotte chose a leader, a Rotmeester, from their midst. ${ }^{19}$

All of these elements were also extant among the Low German foot soldiers of the Netherlands. Emperor Charles V attempted to ban the monthly elections held by his Low German soldiers as early as I 554, and in I 558 his son Philip II endeavoured to usurp the right to appoint the Rotmeesters; but it is not clear whether they were successful. Low German companies still had the traditional Landsknecht organization in I 572-I 573 when serving the States of Holland. ${ }^{20}$ Soon after, Prince William of

17. The first two terms are the Dutch rendition of the German Waibel (or Gemeinwaibel) and Fübrer.

I8. Baumann, Landsknechte, pp. 98-102, I09-II2, II5-I20; Möller, Das Regiment der Landsknechte, pp. I, 4-5, 71-76, 95-100, 213-215. Cf. Cornelis J. Lammers, "Mutiny in Comparative Perspective", International Review of Social History, 48 (2003), pp. 473-482, $476-48$ I.

19. Baumann, Landsknechte, pp. 76, 98, IоI; Möller, Das Regiment der Landsknechte, pp. 50-5 I, 99-100, 109.

20. Articles of war of 4 March I554, Huisarchief Bergh, 's-Heerenberg, inv. no. 38I (art. 40); 
Orange, the military leader of the Revolt, appears to have abolished it. A new organization appeared first in South Holland in I574-1575, with North Holland, relatively isolated after the fall of Haarlem in I 573 , following in I 576- I 577. It definitely no longer contained any posts elected by the soldiers.

The entire company staff was now appointed by the owner of the unit, usually the captain. The Weifels were henceforth known as sergeants and the Rotmeesters became corporals, who, with the assistance of a Lanspassaat, each led an Escuadre of on paper some thirty men. The Voerder had disappeared entirely. Company staff, which under the Landsknechts could vary in size, was standardized at thirteen men. The terminology shows this organization to be of French provenance. ${ }^{21}$ Also, the cadre and internal structure were identical to that of French royal combat companies of foot in I 567 and French companies serving in the Netherlands in $1582 .{ }^{22}$ It is possible that the Huguenot army he served with in I 569 impressed Orange. Gaspard de Coligny, one of its leaders, had a reputation as a strict disciplinarian. During Orange's stay, he managed to lodge the army at an abbey without as much as a window being broken. In the early i 550 , Coligny had drawn up the French articles of war, in use by both sides during the civil wars. ${ }^{23}$ It should also be borne in mind that the Walloon infantry, recruited from among French-speaking Netherlanders, were traditionally organized in the French manner. ${ }^{24}$

At the same time, the Low German companies of foot were substantially reduced in official strength. In keeping with the Landsknechts, these units

Henne, Histoire du règne de Charles-Quint, pp. 53-54. Instruction I6 January I558, in C. Terlinden and Jacques Bolsée (eds), Recueil des ordonnances des Pays Bas, 2nd series VII (Brussels, I957), pp. 266-268; Wijn, "Het Noord-Hollandse regiment", pp. 24 I, 25 I, 258-259. NA, Collection Joachim Ortel, no. 5. NA, Paulus Buys, no. 32.

2 I. Wijn, "Het Noord-Hollandse regiment", pp. 24I-242; Koninklijk Huisarchief, The Hague (KHA), A ir/XIV I/ıi, fos I93-195, fo. I94v-195; NA, Ortel, no. 36; C.M. Schulten, Contribution a l'étude des termes militaires Français en Néerlandais (The Hague, 1966), pp. 50-52, 72, 87, I04, III.

22. John B. Wood, The King's Army: Warfare, Soldiers and Society during the Wars of Religion in France, I562-I576 (Cambridge [etc.], 2002), pp. 88- 90; "Estat de traictement de cent treize testes Infanterie franchoise lesquelz seront traictes et equippez comme sensuyt", in NA, Gemachtigde tot het beleid der financiën en beden I 582 , no. I I.

23. François de La Noue, Discours politiques et militaires (I 587 ), F.E. Sutcliffe (ed.) (Geneva [etc.], I967), pp. 639-642, 782; Brantôme, "Les vies des grands capitaines estrangers", in Oeuvres complètes de Pierre de Bourdeille, seigneur de Brantôme, Ludovic Lalanne (ed.), I 2 vols (Paris, I 864-I896), vol. 2, pp. I65-I66; idem, "Discours sur les couronnels de l'infanterie de France", Oeuvres, vol.6, pp. 16-17, 19-20; Eugène Bersier, Coligny avant les Guerres de Religion (Paris, 2nd edn, I884), pp. 34-35; Liliane Crété, Coligny (n.p., I985), p. 54.

24. Henne, Histoire du règne de Charles-Quint, pp. 46-48, 50-51; M. Beyaert, "De monsterrollen: sleutel tot de reconstructie van het militaire leven in de tweede helft van de $16^{\mathrm{e}}$ eeuw in de Zuidelijke Nederlanden”, Belgisch tijdschrift voor militaire geschiedenis, 2 I (1975), pp. I6I-I 84 and 253-274, 253-260. 
had hitherto been at least 300 strong. In the course of I 573 Orange fixed their strength at I 50 men, which remained the most common size of foot companies in the rebel forces. ${ }^{25}$ The reasons for this reduction may have been partly financial. But when the companies of Walloon infantry were reduced in official size from 500 to 200 men in the 1550 , the reasons given were that this size of unit was more effective in combat, easier to control by captains and was more easily billeted and maintained. ${ }^{26}$ It is very likely that these considerations also played a role for the Prince of Orange. The new size of company was also strikingly similar to that of Huguenot infantry companies. These were reduced in size to I00-150 men shortly after the beginning of the civil wars in $1562 .{ }^{27}$

Basic pay for the Low German infantry had been 5 guilders per month since the beginning of the sixteenth century, the equivalent in local currency of the Landsknechts' basic remuneration of 4 guilders. Because of the high cost of living Orange raised their pay to 8 guilders a month in I $574-1575 .{ }^{28}$ Daily wages in other professions had been rising since c.I 550 , although between I 572 and I 576 the war temporarily interrupted this trend in Holland and Zeeland. By the I 570 s a bricklayer could earn is guilders every 30 days and a builder's labourer between 5 and 9 guilders. ${ }^{29}$ But both the States of Holland in I 572- I 576 and the States General in the late i 570 s and I 580 s had serious problems finding enough money to pay the troops they had hired. They tried to meet this partly by lengthening the pay month, thus effectively annulling the pay rise. The traditional month of 30 days was still attested in I572-I573, but by I 589 at the latest the States General reckoned basic pay at 8 guilders every 48 days, which amounts to the same as 5 guilders per 30 days. ${ }^{30}$

25. Henne, Histoire du règne de Charles-Quint, pp. 48-49; Wijn, "Het Noord-Hollandse regiment", pp. 239-240, 258 ; N.J.M. Dresch, "Rekening van Maerten Ruychaver, thesaurier in het Noorderkwartier, I 572-1 573 ”, Bijdragen en mededelingen van het Historisch Genootschap, 49 (1928), pp. 45-I 27, 74-84; Orange to Captain Philippe de Grenu, I September I 573, KHA, A I I/XIV I/ I 2, fo. 346 (no. I 23); Resolutiën van de Heeren Staten van Hollandt en Westurieslandt (RSH), 25 September I 574; Bor, Oorsprongk, book 7, p. 508.

26. Henne, Histoire du règne de Charles-Quint, pp. 47-48, 52; H.L.G. Guillaume, Histoire de l'infanterie wallone sous la maison d'Espagne (I 500-I800) (Brussels I876), pp. 8-9.

27. Jean de Pablo, “Contribution à l'étude de l'histoire des institutions militaires huguenotes", Archiv für Reformationsgeschichte, 48 (1957), pp. 192-216, 208.

28. Baumann, Landsknechte, pp. 86-90; Möller, Das Regiment der Landsknechte, pp. 77-80; RSH, 30 March I 575 ; NA, Paulus Buys, nos 32 and 73; Reason for pay rise: "overmits die dierte", KHA, A I I/XIV I/I I, fol. I94; Bor, Oorsprongk, book 7, p. 508.

29. De Vries and Van der Woude, The First Modern Economy, pp. 609 and 614, 627-628, 632633; also Leo Noordegraaf, Hollands welvaren? Levensstandaard in Holland 1450-1650 (Bergen, NH, I985), pp. 66-74; A.T. van Deursen, Mensen van klein vermogen. Het "kopergeld" van de Gouden Eeuw (Amsterdam, 1999), pp. I4-I 5, 38-39.

30. Baumann, Landsknechte, p. 87; NA, Paulus Buys, no. 73; RSH, 22 May and I9 June I 576 ; NA, Archives of the States General (loketkast en secrete kast), no. I2579; J.W. Wijn, Het krijgswezen in den tijd van prins Maurits (Utrecht, I934), p. I 2 I. 


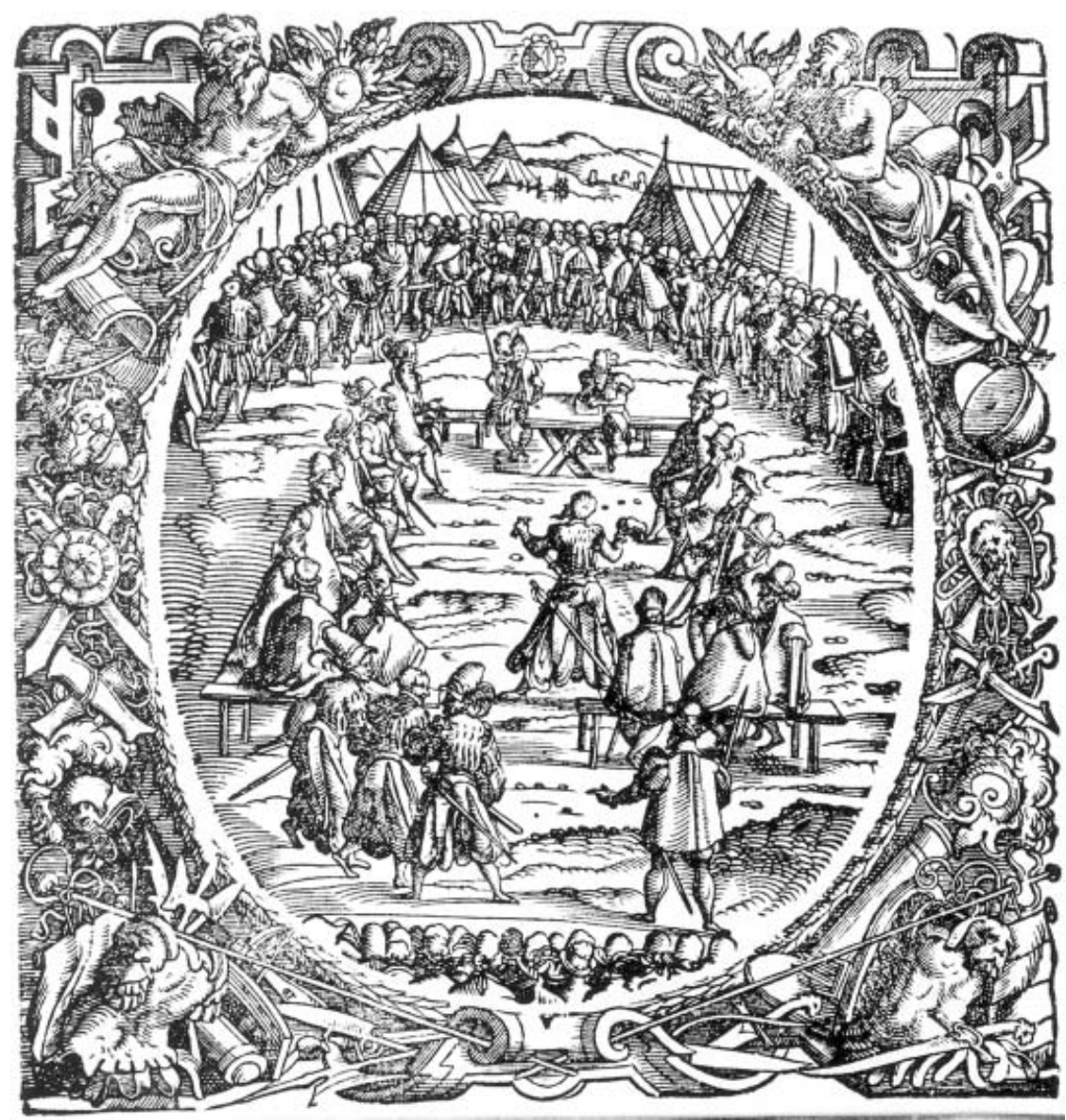

Figure $\mathrm{I}$. This is the sole contemporary image of a regimental Landsknecht court, conducting a full trial under their Malefitzrecht. It takes place in the open air in the presence of the entire regiment.

Leonhart Fronsperger, Von Kayserlichem Kriegssrechten, Malefitz und Schuldhandlen, Ordnung und Regiment etc. (facsimile 1970; Frankfort a/M I 566) fo. II.

With the change in organization the Low German soldiers seem to have lost the means to participate in the administration of justice. The disappearance of the Voerders is probably significant in this respect. The traditional manner of administering justice is still attested in North Holland in I573. With the agreement and participation of his officers and men, Captain Michiel Croocq was sentenced to death in February for murdering a Catholic priest. A full trial under the penal law of the Landsknechts (Malefitzrecht), with its involvement of the ordinary soldiers, was held in Alkmaar in North Holland in December I573; the accused were 
acquitted..$^{31}$ In the articles of war of August I 573 and May I 574 Orange made the administration of justice the domain of the captains. For transgressions committed in garrisons, the captains present were to gather at the governor's house and together pass judgment on the culprit. ${ }^{32}$ Courts martial composed of officers became the normal institutions for the administration of military justice among rebel forces and later in the Dutch Republic. Only in small garrisons with an insufficient number of officers could lower ranks take part in a court martial, but it is unclear whether this actually ever occurred. ${ }^{33}$

\section{THE ARTICLES OF W AR}

The development of the articles of war from a contract into a set of disciplinary rules without any mention of soldiers' rights can clearly be discerned in the articles in use for the rebel troops from I 572 onwards. A set drawn up in I 572 by William of Orange for the garrison of Zaltbommel already contained the increasingly frequent stipulation that the government or prince who had hired the troops had the right to change the articles, albeit with the proviso that the Bevelhebbers (cadre) were to be consulted. This would also include any offices chosen by the soldiers. ${ }^{34}$ In the 1578 articles of the States of Holland, which also applied in Zeeland, this proviso was removed. The Prince now had the right to freely change the articles if he desired to do so. These articles were adopted by the Union of Utrecht the following year. ${ }^{35}$ In another set of articles from I 572 the Ringe is still mentioned. This was the specific, usual manner in which the Gemein of the Landsknechts congregated and asserted their influence. In the same articles the soldiers are directly addressed with "you" ( $U$ and ghy). This was the last time this occurred. ${ }^{36}$

All the articles of war from I572-I573 show another peculiar stipulation - one which occurred frequently until that time. Soldiers had

31. Bor, Oorsprongk, book 6, pp. 434, 457-459; Baumann, Landsknechte, pp. 106-107; Möller, Das Regiment der Landsknechte, pp. I 89-234; A.L.P. de Robaulx de Soumoy, Étude historique sur les tribunaux militaires en Belgique (Brussels, I 858), pp. 17, 20-2 I.

32. Articles 6 August I 573, L.M. Rollin-Couquerque, "Oude strafwetgeving voor ons krijgsvolk te lande I 572-1 705”, Militair-rechtelijk tijdschrift, 38 (1942-1943), pp. 9 I- I 82 and 375-380, 379; Ordinance of I9 May I 574, KHA, A I I/XIV I/I 2, fos 289-290v (art. 27, 30, 33-34).

33. Wijn, Het krijgswezen, pp. 88-92, 94-95.

34. Articles of I 572 , NA, Paulus Buys, no. 73 (last article). Cf. J.J.T. Duval, Geschied- en staatkundige verhandeling over het recht verstand der Unie van Utrecht met betrekking tot de beeren stadhouders van Holland en Zeeland (Utrecht, 1790), bijlagen, p. xxxxi; Baumann, Landsknechte, pp. $82-83$.

35. Ordinance of I 578 , NA, Paulus Buys, no. 37 (art. 42). Articles of I 579, in KHA, A I I/XII 5. 36. Duval, Geschied-en staatkundige verhandeling, bijlagen, pp. xxxiii-xxxiv, xxxviii. Cf. Baumann, Landsknechte, pp. 84, I0I-102, 106-108, I I7, I 19, 190, and Möller, Das Regiment der Landsknechte, passim. 
a tendency to regard their basic pay merely as payment for routine duties. For what they regarded as extraordinary activities, such as a battle or the storming of a breach, they demanded additional money. A variant on this is the article stipulating that if their general won a battle a new pay month would begin for the soldiers. This provision was still included in the articles of $1572-1573$, but is missing thereafter. ${ }^{37}$ In the 1578 articles, the Prince of Orange allowed the soldiers to send up to three representatives to himself and the States of Holland in order to make their grievances known. This seems to be a last echo of the Ambossaten, who are otherwise never heard of again..$^{8}$

Gambling was very popular among soldiers and was generally tolerated, albeit usually with some restrictions. The articles of war would, for instance, specify that it was not allowed during guard duty, that debts should not exceed the soldier's pay, or that their weapons should not be gambled away. The I 572 articles for Zaltbommel state that gaming was allowed only at the "ordained gaming place, and that no one should dare to take the other's money without the acknowledgement of the soldiers present". 39 This article, an expression of the interests of the ordinary soldiers, is never found again. In I585, as Governor-General of the Netherlands, the Earl of Leicester banned gambling outright, but this was reversed in the articles of $1590.4^{\circ}$

Early in the sixteenth century the soldiers' term of service was usually precisely fixed in the articles of war, three months being the minimum. This could cause problems for the government or prince who had hired the troops. If a campaign ended before the three months had expired, they would still have to continue to pay the soldiers; if the campaign lasted longer than expected, their troops might simply go home. This explains why, around I 550, an article began to appear in Germany which stipulated that soldiers had to remain available even after the end of their fixed term of service; by around I600 this had become standard. The next step was that the right of soldiers to a fixed term of service disappeared altogether. ${ }^{4 \mathrm{I}}$ In the Netherlands a set of articles from I 546-I 547 had already stipulated

37. NA, Paulus Buys, no. 73 (art. I3); Duval, Geschied-en staatkundige verhandeling, bijlagen, p. xxxvii; Gemeentearchief 's-Hertogenbosch (GAH), Oud stadsarchief no. I89, fos I 28-I 32, fo. I 29v. Cf. Baumann, Landsknechte, pp. I I I - I I 2; Möller, Das Regiment der Landsknechte, p. 75 ; Burschel, Söldner im Nordwestdeutschland, p. 209; and Wijn, Het krijgswezen, p. 366.

38. NA, Paulus Buys, no. 37 (art. I4); cf. Baumann, Landsknechte, pp. 209-2 Iо.

39. In Dutch: "verordente speelplaetze, und dat sich nyemant vernhemen laten des anderen gelt op te stricken dan bij erkentenisse der gemeijne kriegsluyden die daer ommestaen": NA, Paulus Buys, no. 73 (art. 20).

40. Leicester's articles in C.G. Cruickshank, Elizabeth's Army (Oxford, 2nd edn, I966), p. 298 (art. 4); articles of I 590 in Wijn, Het krijgswezen, pp. 106-107, 557 (art. 73).

4I. Burschel, Söldner im Nordwestdeutschland, pp. 133-135; Möller, Das Regiment der Landsknechte, pp. $84-85$. 
that soldiers were to serve as long as Charles V needed them. The articles of war drawn up by Orange in I 572 and later also lack any reference to a term of service, which probably meant that soldiers joined up for an indefinite period of time..$^{2}$ Those who wanted to leave prematurely had to ask for a passport. Usually this seems to have been granted. For instance, a soldier called Jean Rousel quit service in August I 575 because he wanted to "se retirer en France pour avancer ses affaires particulieres".43

The articles of war of 1590 have been seen as particularly important. Gerhard Oestreich claimed that they were the result of studying the efficiency of classical armies and followed the model of Roman military discipline. ${ }^{44}$ Other historians - J.R. Hale for instance - have maintained that the I 590 articles, which are usually attributed to Maurice of Nassau, were based on Leicester's articles of i 585 . However, questions concerning the basis for Leicester's articles are never asked. The problem here is that there seem to be no precedents in England for such comprehensive articles of war. ${ }^{45}$ Since in plan and contents Leicester's articles barely differ from those drawn up previously by William of Orange, including the unspecified term of service, it is more likely that they were based on those already in use in the Low Countries.

The first articles always concern bans on foul language and mocking religion and they end with the statement that nobody should feign ignorance of the articles. ${ }^{46}$ The articles of war in use among the rebel infantry in fact show a continuous development over the period I 572I 590 , reflecting the change from a contract to a set of disciplinary regulations. This continuity is confirmed by Pieter Bor, who, writing around I600, found it unnecessary to include Orange's articles of I 572 in his work because they were very common and had since then been only somewhat changed and enlarged. 47 The latter assertion is easily proved: in

42. "Artikel brieff Key. ${ }^{\text {te }}$ Mat $^{\text {s }}$ Nederlansche Krygesfolcks etc.", I 546-1 547, Groninger Archieven, Van Ewsum Family Archives, inv. no. 195; NA, Paulus Buys, nos 37 and 73; KHA, A I I/XIV I/ı2, fols 289-289v; GAH, Oud stadsarchief no. i89, fos I28-I32; Duval, Geschied-en staatkundige verhandeling, bijlagen, pp. xxxiii-xxxxi.

43. Passport dated 3 August i 575, KHA, A I I/XIV I/I I, fo. 90 (no. 202); also fo. Io8 (no. 238 ).

44. Gerhard Oestreich, Neostoicism and the Early Modern State, Brigitta Oestreich and H.G. Koenigsberger (eds) (Cambridge [etc.], I982), p. 4. Cf. H.L. Zwitzer, "Machiavelli, Maurits en Willem Lodewijk: tijdgenoten op afstand", Mededelingen van de Sectie Militaire Geschiedenis, Io (1987), pp. 5-17, 5-6, 17.

45. Hale, War and Society, p. I69, but also B.H. Nickle, "The Military Reforms of Prince Maurice of Nassau" (Ph.D., University of Delaware, 1975), pp. 94-95, 250 . On English articles of war before Leicester see Cruickshank, Elizabeth's Army, pp. I 59-I6I.

46. Articles I 574, KHA, Ai i/XIV I/I I, fos 289-290v; Articles i 578, NA, Paulus Buys, no. 37; Articles 1585, Cruickshank, Elizabeth's Army, pp. 296-303; Articles 1590, Wijn, Het krijgswezen, pp. 546-558.

47. Bor, Oorsprongk, book 6, p. 4I4. 
I 574 the articles of war consisted of thirty-four articles, in I 578 there were forty-eight, in 1585 already fifty-five, and finally in I 590 no less than eighty-two. The articles of I 590 were, with some revision in 1705 , retained until $1799 .^{48}$ This in itself constitutes sufficient evidence that the transformation of the articles of war had been completed.

\section{MANUAL LABOUR}

Soldiers in the sixteenth century thought the manual labour that came with military life, such as digging trenches, constructing sconces, and clearing roads, beneath their dignity. This work was done by pioneers, who were either local peasants pressed into service or labourers organized in companies along military lines. The pioneers were at the bottom of the social ladder in the army, looked down upon and despised by the soldiers; they were also victims of abuse and mistreatment. The I 546-i 547 articles of war contain an article forbidding the soldiers to bother the pioneers or steal from them. ${ }^{49}$ In I 555 Governess-General Mary of Hungary tried to improve their status by raising their pay from five to six guilders a month and henceforth referring to them as manoewvriers since they detested the designation pionniers. But this had no effect and by i 557 pay had decreased to its previous level. ${ }^{\circ}$

In spite of the soldiers' resentment against manual labour, they were increasingly obliged to do this work in the course of the second half of the sixteenth century. There were two reasons for this. First of all, pioneers were simply not always available. They might have deserted in droves or been decimated by disease, and their work would still have to be done. Secondly, the increasing impoverishment of the soldiers made the extra money they could earn as pioneers very alluring. Both reasons can be amply illustrated. As early as the I554 campaign against the French, entire regiments of the Habsburg army were forced to aid in the construction of new fortifications. In order to overcome the soldiers' unwillingness, their commanders, including William of Orange, the Count of Arenberg, and the Captain-General the Duke of Savoy, set an example by personally wielding a shovel. Soldiers who still refused were dismissed without pay. Individual soldiers volunteered for work as pioneers to earn extra money. The same occurred during the campaign of $1557.5 \mathrm{I}$

48. Rollin-Couquerque, “Oude strafwetgeving”, pp. 96-97. See n. 46.

49. "Artikel brieff", I 546-I 547, Groninger Archieven, Van Ewsum, no. I95 (art. 30); Burschel, Söldner im Nordwestdeutschland, pp. I 38, 255 .

50. B. Roosens, "De keizerlijke artillerie op het einde van de regering van Karel V", Belgisch tijdschrift voor militaire geschiedenis, 23 (1979), pp. I17-I35, I23-I 24.

5I. C.A. Rethaan Macaré (ed.), "Dagverhaal van den veldtogt van keizer Karel V in I554", Kronijk van het Historisch Genootschap gevestigd te Utrecht, 7 (185 I), pp. 280-308, 296-297, 302-303; C.A. Rethaan Macaré (ed.), "Veldtogt van koning Philips II tegen Frankrijk in I 557", 
During the French civil wars of the I 560 and I570s, individual Swiss and German soldiers proved willing to work in the trenches. Swiss soldiers entering Venetian service in I 57 I were paid extra if they performed more than two days of labour. The German articles of war laid down by the Imperial Diet of I 570 contained an article stating that in cases of necessity soldiers could not refuse employment as labourers or builders. ${ }^{22}$ There was no such article in the articles for the foot soldiers of the rebel Netherlanders after I572, but these foot soldiers did construct fieldworks themselves whenever necessary. On the opposite side, the Prince of Parma, in an attempt to overcome the resentment of his infantrymen, personally wielded a shovel during the sieges of Zichem (I578) and Maastricht (1579). English soldiers in the service of King Henry IV of France during the siege of Rouen in I 59I also did the work of pioneers. ${ }^{53}$

It has been claimed that it was Maurice of Nassau who first made his soldiers use a shovel and pickaxe, supported by classical examples supplied by Justus Lipsius, ${ }^{54}$ but this abundance of examples testifies otherwise. In reality the soldiers suffered from long-term pressures exerted on them, both by the people who had hired them and by their own increasing poverty, compelling them to perform the much detested manual labour themselves, resulting in - and exemplifying - a loss of social status.

\section{WOMEN, CHILDREN AND SERVANTS}

Sixteenth-century armies were composed not just of military men, but carried an extensive train with them. This included sutlers and prostitutes but also the soldiers' wives, children, and servants. The latter were called jongens (boys) in Dutch. The train was an ever-present appendage of the army, supplying soldiers with necessary victuals, goods, and services; without an extensive train a sixteenth-century army could not function properly. In spite of this, the governments or princes who had hired the troops and the commanders who led them in the field generally resented

Kronijk van het Historisch Genootschap gevestigd te Utrecht, 7 (I85I), pp. 3I2-340, 33 I, 334-335.

52. Wood, The King's Army, pp. I I I-I I 2, I65, 264-265, 267. On the Swiss in Venetian service, see Hale, War and Society, p. 71. On the German articles of I 570 , see Johann Christian Lünig, Corpus iuris militaris des Heil. Röm. Reichs (Leipzig, I723), pp. 58-76, 7 I.

53. Bor, Oorsprongk, book 7, pp. 555, 620; R. Fruin (ed.), "Journaal van Splinter Helmich, soldaat en later hopman in dienst van den lande, van I 572 tot I 589 ", Kroniek van het Historisch Genootschap, 3 I (1875), pp. I59-28 I, I9I. On Parma, see Wijn, Het krijgswezen, p. 281. On English soldiers in I591, see Hale, War and Society, pp. 177-178.

54. Cf. Oestreich, Neostoicism, p. 77; E.H. Waterbolk, "Everard van Reyd (1550-1602), geschiedschrijver en militair adviseur”, in P.A.M. Geurts and A.E.M. Janssen (eds), Geschiedschrijving in Nederland. Studies over de historiografie van de Niewwe Tijd I Geschiedschrijvers (The Hague, I98 I), pp. 4I-63, 53-54; Burschel, Söldner im Nordwestdentschland, pp. I38-139; also C. Duffy, The Fortress in the Early Modern World, I494-I660 (London, I979), pp. 64, 81. 
the presence of increasing numbers of camp followers, who could easily outnumber the actual fighting men.55 They increasingly tried to regulate the train and reduce it in size. From the middle of the sixteenth century a general change in moral attitudes, especially attempts to improve sexual manners, associated with the Reformation, may have begun to play a role as well. Whereas previously even the concubines or bedfellows of Landsknechts were accorded legal rights such as full rights of inheritance, the German articles of war of I570 labelled them "lewd women" (unzüchtige Weiber) and forbade their presence in camp. ${ }^{.6}$

This development was also apparent in the rebel provinces of the Netherlands. Orange's articles of war from I 572 onwards allowed soldiers to have only their legal spouses (echte vrouwen) with them. Those who lived with concubines or prostitutes were to be punished. The I 574 articles prescribed for both the soldiers and the women in question a public flogging and subsequent dismissal.57 In the 1578 articles there is no mention of the women, but the 1585 articles again allow only lawful wives, besides women to care for the sick and tend to the laundry, upon the same punishment as in I $574 .{ }^{58}$ Similarly, the articles of I 590 banned prostitutes, but whether these regulations regarding female camp followers had any practical effect is debatable. ${ }^{99}$ Prostitutes remained an integral part of the military entourage.

The inhabitants of the rebel provinces generally had a strong aversion to the soldiers fighting their cause and they extended their dislike to the soldiers' women and children. In I 576 for instance, the garrison of the besieged city of Zierikzee complained about the treatment of their women in Middelburg: the States of Zeeland had resolved to expel them from the country. Orange's military governor in Zeeland had to take them under his protection. ${ }^{60}$ It is striking that around Zoetermeer, a village near The Hague, in I572-I573 women and jongens seem to have been billeted with

55. Baumann, Landsknechte, pp. 146-165; Burschel, Söldner im Nordwestdeutschland, pp. 226258; Wood, The King's Army, pp. 304-305. Cf. Peter-Michael Hahn, "Kriegserfahrungen von Kindern und Jugendlichen im Zeitalter des Dreißigjährigen Krieges”, in Dittmar Dahlmann (ed.), Kinder und Jugendliche in Krieg und Revolution. Vom Dreißigjährigen Krieg bis zu den Kindsoldaten Afrikas (Paderborn [etc.], 2000), pp. I-I 5, 2-3, I0-I I.

56. Peter H. Wilson, "German Women and War, I 500-1800", War in History, 3 (1996), pp. I 27-I60, I 28, I 30-I32, I 59; Baumann, Landsknechte, pp. I 54-I 56, 20I-202; Lünig, Corpus iuris militaris, p. 62 (art. 43); Henry Kamen, Early Modern European Society (London [etc.], 2000), pp. $178-179$.

57. For I 572 , see Duval, Geschied-en staatkundige verhandeling, bijlagen, p. xxxx. For I 573 , see GAH, Oud stadsarchief no. I89, fo. I 3 I. For I 574, see KHA, A I I/XIV I/I 2, fo. 289 (art. 6). 58. For the I 578 articles see NA, Paulus Buys, no. 37; Cruickshank, Elizabeth's Army, pp. I63, 179, 298 (art. 5).

59. Wijn, Het krïgswezen, pp. 107-108, 546-547 (art. 4).

60. Haultain to Orange, 29 March I576, G. Groen van Prinsterer (ed.), Archives ou correspondance inédite de la Maison d'Orange-Nassau, Première série, supplément (Leiden, 
the soldiers and were reckoned separately at costs of five stuivers a day. ${ }^{6 \mathrm{I}}$ This never occurred again. The soldiers were initially entitled to free billets with heat and lighting. The latter was abolished and from late I 576 on soldiers' hosts received recompense in the form of logiesgeld (billet money) amounting to around seven stuivers a week. But garrison towns did not have to supply the women, children and servants with anything. In I 580 Orange issued an ordinance on billeting, ordaining that soldiers with wives, children and other useless followers (onnutte naeloop) were to find their own lodgings and should not bother the magistrate. ${ }^{62}$ In 1588 mutinous soldiers in North Holland complained about the continual snubbing of their wives and children, who were never given anything. ${ }^{63}$

With onnutte naeloop Orange would certainly have meant the jongens, the soldiers' servants who did many menial tasks and daily chores. This included cleaning and carrying soldiers' equipment and other possessions, but also gathering or stealing food and collecting loot. For the soldiers these servants were a privilege they believed they were entitled to, an expression of the social position they thought they had: in their own eyes the soldiers were something better than mere labourers or peasants. ${ }^{64}$ The articles of war say very little about the jongens, but the authorities' negative attitude towards the soldiers' servants is clear enough. ${ }^{65}$ It would also have been increasingly difficult for the badly paid, impoverished soldiers to support servants.

The German historian Peter Burschel maintains that the office of Hurenwaibel (in Dutch hoerenweifel) became a victim of the "new morality", the desire of the authorities to impose their moral laws, introduced for the civilian population during the Reformation, on the military. ${ }^{66}$ This officer, often an old soldier no longer fit for regular duty, was charged with the important duty of leading the train of camp followers and making sure they did not impede military movements. Every regiment of Landsknechts and their Low German counterparts usually had one. Sometimes they were attached to companies. ${ }^{67}$ Their

I 847), pp. I83-i 85; Also Orange to magistrate of Oisterwijk, I 2 December I 573, KHA, A I I/ XIV I/I 2, fol. 480 (no. I75).

6r. Gemeentearchief Zoetermeer (GAZ), PB Zegwaart 252, fos 3-8v, I3-26v.

62. Ordinance of I 580 , Het Utrechts Archief (HUA), Hof van Utrecht, 29-2, fos 357-36Iv; Orange to magistrate of Geertruidenberg, 7 November i 573, KHA, A I I/XIV I/8, I67; NA, Paulus Buys, no. 38 (art. 16-20). RSH, 27 November, 7 December I 576, 26 June I 577, I 4 February I 584 ; Gemeentearchief IJsselstein, Oud Archief IJsselstein, no. 59.

63. Bor, Oorsprongk, book 24, p. I88.

64. Burschel, Söldner im Nordwestdeutschland, pp. 252-255; Wood, The King's Army, p. 304; Hahn, "Kriegserfahrungen", pp. I I-I3.

65. Cf. NA, Paulus Buys, no. 37 (art. 39).

66. Burschel, Söldner im Nordwestdentschland, pp. I36-137, 257-258.

67. Baumann, Landsknechte, pp. 94, I 50-I I I, I 53 ; Möller, Das Regiment der Landsknechte, pp. I77-I 82. Johan van Ewsum's company had one in I 536, Groninger Archieven, Van Ewsum, no. 


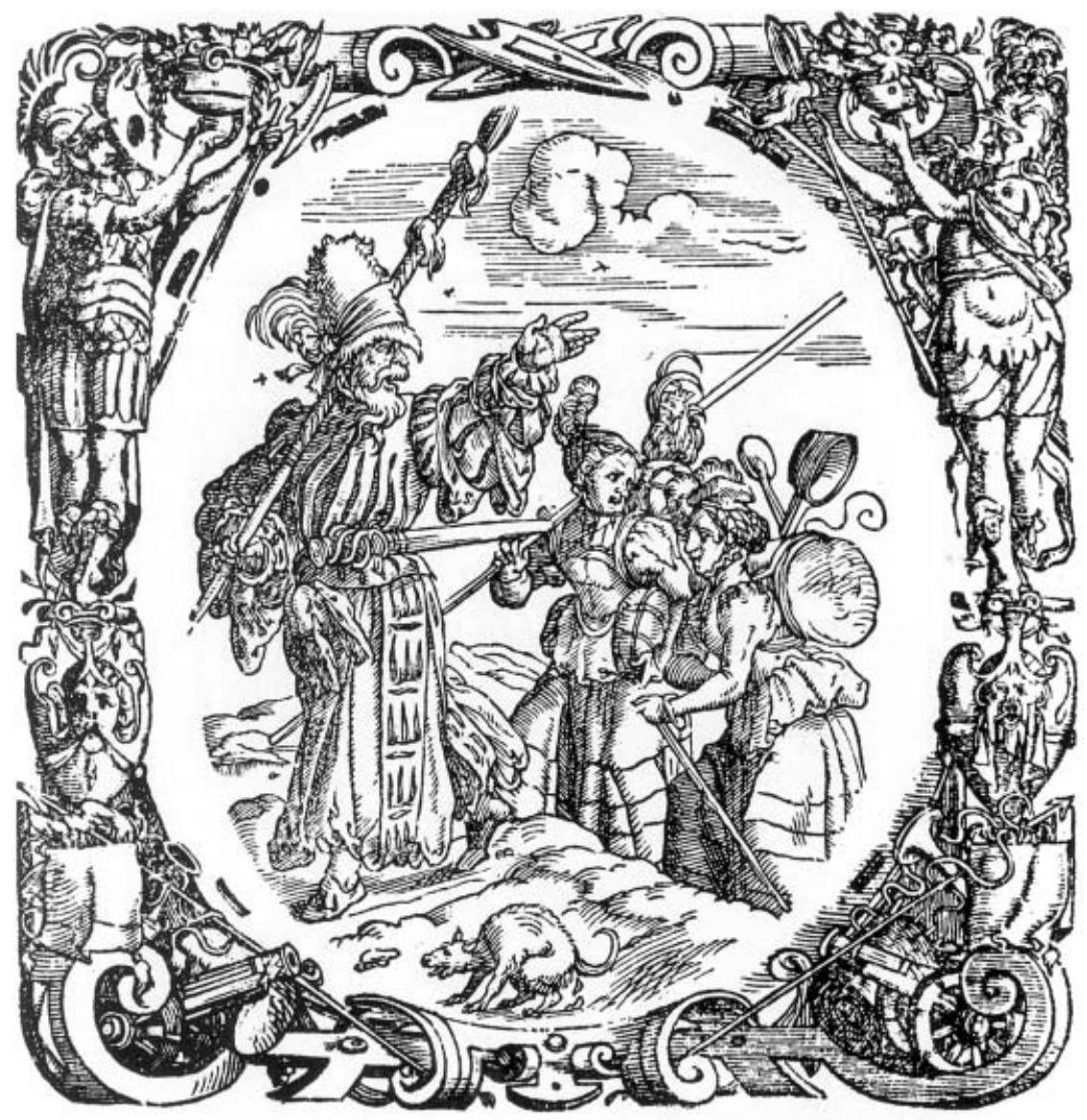

Figure 2. Contemporary impression of a Hurenwaibel followed by some of his laden female charges.

Leonhart Fronsperger, Von Kayserlichem Kriegssrechten, Malefitz und Schuldhandlen, Ordnung und Regiment etc. (facsimile 1970; Frankfort a/M I566) fo. $138 v$.

presence in the Netherlands is still attested in 1566 , but from 1572 onwards there is no mention of them in the rebel forces. In the German states the Hurenwaibel was done away with during the Thirty Years War (I6I8-1648) or shortly thereafter; the Swedish king Gustavus Adolphus abolished him in $162 \mathrm{I}^{68}$

I 89; Orange's regiment in I552, KHA, A I I/X 3 . See also Henne, Histoire du règne de CharlesQuint, pp. 52-53,63.

68. Beyaert, "De monsterrollen”, pp. I67-168 (n. 36). 


\section{CONCLUSION: CHANGE AND RESISTANCE}

Whether the moral attitudes of the Reformation played a role in driving the changes affecting the Low German foot soldiers of the Low Countries is difficult to ascertain but seems doubtful. The reduction in the size of the Walloon foot companies had already taken place in the Is sos during the war with France, mainly for military and financial reasons. During the same decade, Charles V and Philip II attempted to curb pillaging by their soldiers and former soldiers in the southern Low Countries. In an ordinance of I 556 Philip expressed his fear that the victims might become less able or even unable to contribute towards paying for the war. ${ }^{69}$

After I 572 the need to gain more control over the often appalling behaviour of the soldiers became acute. For the Revolt to succeed, it was imperative for Orange to maintain the support of the people who had to pay for it. These people resented the presence of soldiers and their onnutte naeloop in their communities to begin with, and the intimidation, violence, rape, and looting that came with the military could alienate them from the rebel cause. ${ }^{70}$ Orange therefore had to attempt to control his soldiers and enforce discipline. A shortage of money played a further role in sapping the position of the ordinary soldiers in the I 570 s and I $580 \mathrm{~s}$. A pay rise by Orange was nullified and by i 589 the soldier's pay was no better in real terms than it had been at the beginning of the century. The low basic pay of ordinary soldiers in comparison with other sectors echoes the situation of the sailors of the navy and the East India Company early in the seventeenth century, who earned less than their counterparts in the merchant navy and could scarcely maintain a family or pay for regular housing. ${ }^{\text {I }}$

Why did the soldiers not resist their decline in social status and power? There is evidence that some soldiers did object to Orange's regulations and ordinances. In March I 574 Captain Nicolaes Ruychaver notified his immediate superior, Diederik Sonoy, Orange's deputy in North Holland, that his soldiers objected to their company being reduced to i 50 men. They were also unhappy that their wives and children were not allowed to accompany them during marches and were instead to be dispersed over villages and make themselves useful by spinning. Sonoy's answer to the Captain was curt: Orange wanted it that way, it was not up to him to change this, and Ruychaver was to regulate accordingly. If the soldiers

69. Henne, Histoire du règne de Charles-Quint, pp. 47-48, 52; Guillaume, Histoire de l'infanterie wallone, pp. 8-9; Beyaert, "De monsterrollen", pp. I66-i67 (n. 33), I71, I82.

70. See for instance letters by the magistrates of Leiden to Orange from I 573 complaining about the shocking behaviour of their garrison and warning him that the citizens threatened to turn on them; KHA, A I I/XIV E/24.

7I. J. Lucassen, "Zeevarenden", in L.M. Akveld, S. Hart, and W.J. van Hoboken (eds), Maritieme geschiedenis der Nederlanden II Zeventiende eeww, van I585 tot ca. I680 (Bussum, I977), pp. I26-I 58, I44. 
refused to comply, Sonoy would discharge the entire company. ${ }^{72}$ This threat hints at what was the problem for ordinary soldiers: they had nowhere else to go. Impoverishment had led to a situation where the alternative to soldiering was unemployment, begging, vagabondage, or crime. ${ }^{73}$ In this respect, it is telling that when in I 588 Sonoy's soldiers complained of strict discipline and severe punishments for small offences such as stealing an egg or a duck, they made it clear that they were prepared to accept this provided their pay arrived on time. ${ }^{74}$ The soldiers' dependence on their pay mirrors the process of proletarianization discernable in other sectors of the Dutch economy.

Traditionally, historiography has attributed certain crucial developments in the field of military organization and discipline to Maurice of Nassau. These developments have been linked to state building and the birth of the Dutch Republic. ${ }^{75}$ But, as this article has shown, important developments had already taken place in the decades before Maurice. Indeed, many developments in the organization, command, and control of armies in the sixteenth and seventeenth centuries were long term, gradual, and continuous. These developments were brought about by political circumstances, events and decisions, facilitated by social and economic trends and shaped by cultural factors. Political circumstances in the rebellious provinces of the Netherlands after i 572 caused military changes to accelerate compared with, for instance, the German Empire. ${ }^{76}$ The States' army was not born under Maurice of Nassau; it already existed when he succeeded his father. It was an army in which the ordinary foot soldier had already lost his status of Landsknecht - with the right to participate in decisions and shape his daily life - and had become accustomed to stricter discipline and a more hierarchical company organization. He had in fact become a "soldier".

72. Two letters from Sonoy to Ruychaver, is and I7 March I 574 (in haste), Rijksarchief NoordHolland (RANH), Ruychaver Papers, nos $8 \mathrm{I}$ and 84; letter from Muster Commissioner Cornelis van Rijswijck to Ruychaver, I4 March I 574, RANH, Ruychaver, no. 80.

73. Baumann, Landsknechte, p. 210. Cf. Burschel, Söldner im Nordwestdeutschland, pp. $298-299$.

74. Bor, Oorsprongk, book 24, p. I 88.

75. Jonathan I. Israel, The Dutch Republic: Its Rise, Greatness, and Fall, I477-I806 (Oxford [etc.], 1998), pp. 267-271; Werner Hahlweg, Die Heeresreform der Oranier und die Antike. Studien zur Geschichte des Kriegswesens der Niederlande, Deutschlands, Frankreichs, Englands, Italiens, Spaniens und der Schweiz vom Jahre I589 bis zum Dreissigjährigen Kriege (Berlin, I94I); idem, "Aspekte und Probleme der Reform des niederländischen Kriegswesens unter Prinz Moritz von Oranien”, Bijdragen en Mededelingen betreffende de Geschiedenis der Nederlanden, 86 (1971), pp. I6I-177; Parker, The Military Revolution, pp. I 8-23.

76. Cf. Burschel, Söldner im Nordwestdeutschland, pp. 318-320. Also Michael Sikora, "Söldner - historische Annäherung an einen Kriegertypus”, Geschichte und Gesellschaft, 29 (2003), pp. $210-238,226$. 